SKULL CREEK: Christmas Week, 1950 . Birds noted while going about daily work on ranch. Mallard, 1; Golden Eag: le, 1; Prairie Falc on, 1; Ruffed Grouse, 1; Prairie Chick en (Sharp tailed?) 16; Hungarian Partridge, 11; Ring-necked Pheasant, 1; Great horned Owl, 2; Snowy Owl, 2; Yellow-shafted Flicker, 1; Hairy Woodpecker, 2; Horned Lark, 21; Am. Magpie, 22; Black-capped Chickadee, 6; English Sparrow, 33; P ine Gros beak, 15; Common Redpoll, 200 to $300 ;$ Tree sparrow, 12; Snow Bunting, 16.

Steve A. Mann.

WALL WORT: Dec. 27, 1950. 3 mile walk north on Highway 35 and 4 miles north on side road, and about the home farm yard. Sharp-tailed Grouse, 7; Canada Jay, 3; Raven, 2; Hairy Wood- peck er, 2; Downy Woodpecker, 1; Blackcapped Chickadee, 6; Pine Grosbeak, 5. J. Turnquist.

YORKTON: Dec. $26,1950.9$ a.m. to $3.30 \mathrm{p.m}$. 12 obs ervers in 4 parties. Total party hours, $6^{2} / 2$ ( 3 on foot, $3 \frac{1}{2}$ by car); total party miles, 34 ( 3 on foot, 31 by car). Great Horned Owl, 1; Snowy Owl, 2; Downy Woodp ecker, 2; Bl ue Jay, 2; Am. Magpie, 1; Bl ack-capped Chickadee, 4; Cedar Waxwing, 52; English Sparrow, 54; Common Redpoll, 5; Snow Bunting, 518 .

Mary Belcher, Jerry Bulitz, Brother Clarence, Lionel Coleman, Ronald Coleman, Glen Dawes, C. Stuart Houston Dr. C. J. Houston, Dr. S. C. Houston, Cliff Shaw, Jeff Smith, Brother Vincent. ( Members of Yorkton Natural History Society ).

\title{
A Bird Count Suggestion
}

\author{
Marion Nixon, Wauchope
}

I have a suggestion to make that has crystallized over a period of years. Would it not give a truer picture of birds present if a longer period than one day were taken into consideration for the bird count ... say all Christmas week, or even the last fortnight of the year .. but the number reported being the largest number of any one species, seen on one dây during that time.

It is, of course feasible to make a quite comprehensive survey if a club goes out in separate parties, over different areas, to cover a territory in one day. But for the average farmer reporting, this is not a logical count. His bird watching is done incidentally, from a straw rack or on the road to town and over a period of time he sees more birds, of more species, than on any particular day. The gypsy migrants come and go, and even the ma gpies appear in larger congregations if there is offal about.

I have noticed a tendency towards this kind of report in some of your final analyses of winter bird populations, but I believe if you made my suggestion a rule, you would get population re ports on all the species rather than just remarks regarding rare appearances.

\section{Our Pet Oriole}

GERALD BRITTON, (Age 11), Homefield, Sask.

One day last spring a baby oriole fell out of its nest and couldn't get back, as it was not strong enough to do more than flutter around. We were going to put it back into the nest but it wa.s raining and every thing was soaking wot so we decided to keep it until the weather cleared'up. When we went back the old orioles had gone. We realized then that if we did put it back it would have no one to feed it.
It grew up, and became a real pet. We fed it bread-crumbs and water, but it soon learned to help its elf to the jam Whenever we went to the doorstep it would come and land on our heads. Before long it began to visit the neighbors. It stayed there for about a month. Then one day it disappeared. Perhaps it was killed by a cat, but we still hope that it flew south with all the other orioles. 